Vol. 44, N. 2 : pp. 135 - 140, June, 2001

ISSN 1516-8913 Printed in Brazil

\title{
Effects of Trace Volatile Organic Compounds on Methane Oxidation
}

\author{
Wilai Chiemchaisri ${ }^{1}$, Chettiyappan Visvanathan ${ }^{1 *}$ and Jy Shing $\mathrm{Wu}^{2}$ \\ ${ }^{1}$ Environmental Engineering Program, School of Environment, Resources and Development, Asian Institute of \\ Technology, Pathumthani, 12120 Thailand; ${ }^{2}$ Department of Civil Engineering, University of North Carolina at \\ Charlotte, Charlotte, NC 28223, USA
}

\begin{abstract}
The effects of volatile organic compounds (VOCs) on methane oxidation in landfill cover soils were examined. The batch experiments were conducted using single and mixed VOCs, such as, dichloromethane (DCM), trichloroethylene (TCE), tetrachloroethylene (PCE), and benzene. The results from all combinations showed a decrease in methane oxidation rate with increase in VOC concentrations. Moreover, inhibition effects of TCE and $D C M$ were found higher than benzene and PCE. The reduction of methane oxidation by benzene and PCE could be attributed to the toxicity effect, whereas TCE and DCM were found to exhibit the competitive-inhibition effect. When the soil was mixed with DCM, no methane oxidation was found. Damage to the cell's internal membrane was found in a methanotrophic culture exposed to VOC gases which is the attachment site of a key enzyme needed for methane oxidation
\end{abstract}

Key words: Landfill cover soils, methane, methanotrophs, methane oxidation, volatile organic compounds (VOCs)

\section{INTRODUCTION}

Landfills are important sources of greenhouse gases. Landfill gas consists mainly of methane and carbon dioxide. Currently, methane has received more attention due to its higher global warming potential compared to carbon dioxide. The annual rate of methane emission from landfills has been estimated to be 20 to 70 millions tons (IPCC, 1992) and is expected to rise as development continue towards the construction of sanitary landfills, in many countries.

Microbial activities in a landfill are complex and interrelated, particularly within the cover soil layer where the oxidation of methane takes place in the presence of naturally occurring methanotrophs. Many researchers have reported the phenomenon of methane oxidation in landfill cover soil by methanotrophic bacteria and identified the various factors which control methane oxidation (Whalen et al., 1990; Boeckx and Cleemput, 1996; Bojesson and Svensson, 1997). These researchers have identified soil texture, moisture content, temperature, nutrients, methane and oxygen concentrations as main factors. If favorable conditions are maintained, the landfill cover soil can serve as an effective sink for methane (Visvanathan et al. 1999, Humer and Lechhner, 1999). This natural microbial activity could be an

* Author for correspondence 
alternative inexpensive method to control methane emission from landfills.

Besides methane and carbon dioxide, several types of volatile organic compounds (VOCs) such as alkanes, cycloalkanes and halogenated compounds have been detected in landfill gases. Total global VOC emissions from landfills have been estimated to be of the order of $10^{12} \mathrm{~kg} / \mathrm{y}$ (Allen et al, 1997). Presence of VOC in landfill gases, could affect microbial activity in cover soils. Identification of the effects of major VOCs on methane oxidation could be helpful in assessing the methane oxidation status of a landfill cover soil. The aim of this study was to investigate the effects of VOCs on methane oxidation rate (would it be better to indicate that the rate was examined in batch cultivation of methanotrophs. The VOCs selected for this research were dichloromethane, trichloroethylene, tetrachloroethylene, and benzene, because they are often found in landfill gases in very high concentrations. TCE, PCE, benzene and DCM concentrations in landfill gases are found in ranges of 0.001-20, 0.1-62, 1.5-29 and 0.06-260 ppmv, respectively (Air Resources Board, 1989). Batch experiments were performed to examine the effect of single and mixed VOCs on methane oxidation rates. The effects of VOCs on methanotrophic bacterial cell were also studied using transmission electron microscope (TEM).

\section{MATERIALS AND METHODS}

Effect of Single VOC on Methane Oxidation Activity: Soil samples used for this experiment were taken from a simulated landfill cover soil column which had been purged with a synthetic landfill gas (60:40 of $\mathrm{CH}_{4}$ to $\left.\mathrm{CO}_{2}\right)$ for 18 months (Visvanathan et al., 1999). The experiments were performed on duplicate samples. Five grams of simulated landfill soil was transferred to $118-\mathrm{mL}$ serum bottles. Initial water content of soil samples was set to an optimum of $15 \%$ as reported by Visvanathan et al. (1999). VOCs in liquid form were transferred into small tubes and these tubes were placed inside the serum bottles. The serum bottles were immediately closed with Teflon-lined silicone lids with aluminum caps and incubated at $30^{\circ} \mathrm{C}$ for one hour to ensure the complete volatilization of VOCs. The VOC concentrations (in the headspace) were monitored regularly. The VOC concentrations set up in the headspace were: TCE: 0, 4.5, 10.7, 19.6, 31.2 ppmv; PCE: 0, 7.0, 13.9, 27.9, 41.9, 69.9 ppmv; benzene: 0, 3.8, 7.6, 15.1, 30.2, 45.4 ppmv; and DCM: 0, 5.7, 11.4, $22.8,34.1 \mathrm{ppmv}$. In order to simulate the filed conditions, the VOC concentrations were generally set up in the ranges of actual concentrations found in landfill gases. Headspace methane concentration was set to $5.0 \pm 0.5 \%$ with the help of gas-tight syringe. Concentration of methane in headspace gas was measured using Gas Chromatograph at different time interval (GC, Shimadzu-14A; detector, TCD; carrier gas, helium with flow rate $35 \mathrm{ml} / \mathrm{min}$; column: stainless steel, ID $2.5 \mathrm{~mm}, 1.8 \mathrm{~m}$ length; supporting material, WG-100; injection, column and detector temperature, $50^{\circ} \mathrm{C}$; TCD temperature, $100{ }^{\circ} \mathrm{C}$; current, $103 \mathrm{mv}$ ).

Effect of Mixed VOCs on Methane Oxidation Rate: Five sets of experiments with mixed VOC concentrations were performed as shown in Table 1. This total VOC concentration was based on the experimental field study carried out by Ward et al (1996) and Air Resources Board, 1989.

Table 1 - Types and concentrations of VOCs in the mixed VOCs experiment.

\begin{tabular}{lll}
\hline Condition & Mixed VOC $($ ppmv $)$ & Total VOC concentration, ppmv \\
\hline Set 1 & PCE (7.6) + Benzene (13.9) & 21.6 \\
Set 2 & DCM (11.4) + Benzene (13.9) & 24.4 \\
Set 3 & DCM (11.4) + PCE (13.9) & 25.3 \\
Set 4 & DCM (11.4) + TCE (11) & 22.4 \\
Set 5 & DCM (11.4) + Benzene (13.9) + PCE (13.9) + TCE (11) & 50.2 \\
\hline
\end{tabular}

Note: Soils without VOC, and with each single VOC in the same concentration of tests (in blanket) were also prepared as the controls. 
Effect of VOCs on Methanotrophic Cells: This study was made to observe the effect of VOC on methanotrophic bacterial cell structure. Transmission electron microscope (TEM, JEOL: JEM-200CX, the accelerating voltage $100 \mathrm{KV}$ ) was used to view the methanotrophic cells. A culture of Methylomonas methanica (Type I) isolated from the soil lysimeter was used in this experiment. Subculture was prepared in eight 118$\mathrm{mL}$ bottles containing 10-mL of Nitrate Mineral Salts media (Writtenbury, 1970) and 10-mL of methane gas. Then, liquid VOCs were injected into the culture bottles with concentrations of 5 ppmv of DCM, 5 ppmv of TCE, 40 ppmv of PCE and $30 \mathrm{ppmv}$ of benzene. These VOC concentrations were fixed based on the results of single VOC experiments with $30-60 \%$ reduction of methane oxidation rate. All sets were conducted in duplicate samples. The cultures were incubated at $30^{\circ} \mathrm{C}$ in shaking incubator, and were harvested for TEM examination once the flocs of cultures appeared in 1-2 weeks. Treatment of cultures for TEM examination was performed using the method described by Scott et al (1981).

Data Analysis: Since methanotrophs can cometabolize some VOCs with competitive-inhibited methane oxidation, we hypothesized that the competitive-inhibition mechanisms may be occurring in all VOCs used in this study. The competitive-inhibition equation used for calculating the methane oxidation rate inhibited by VOC is as follows (Alvarez-Cohen and McCarty, 1991):

$$
-\frac{d S_{i}}{d t}=\frac{k_{i} X S_{i}}{K_{s i}\left(1+\frac{S_{j}}{K_{s j}}\right)+S_{i}}
$$

where $S_{i}$ is the mass of compound $i$ in headspace at time $t(\mathrm{mg}), X$ is soil mass at time $t$ (g dry soil), $k_{i}$ is the maximum transformation rate of $i(\mathrm{mg}$ of $i / \mathrm{g}$ dry soil.d), and $K_{s i}$ is the half velocity constant for $i(\mathrm{mg}) . \quad S_{j}$ is the content of co-metabolized compound $j$ in headspace at time $t(\mathrm{mg})$ and $K_{s j}$ is the half velocity constant for $j(\mathrm{mg})$.

Subscripts $i$ and $j$ refer to methane and cometabolized compounds (VOC), respectively. The reaction constants for methane used in this study were $K_{s i}\left(3.46 \mathrm{mg} \mathrm{CH}_{4}\right), k_{i}\left(430 \times 10^{-6} \mathrm{~g} \mathrm{CH}_{4} / \mathrm{g}\right.$ dry soil. d) (Visvanathan et al, 1999). The rate of disappearance of methane can be calculated from equation (1).

\section{RESULTS AND DISCUSSION}

Effect of Single VOC on Methane Oxidation Activity: Figures 1 and 2 illustrate the effects of VOCs on methane oxidation rate. From these figures, it can be seen that increase in VOCs concentrations could result in decrease in methane oxidation rate. However, the trend of inhibition effect on methane oxidation rate was found different for each VOC. The methane oxidation rate was found to decrease slowly with increase in benzene and PCE concentrations. However, a rapid decrease in the methane oxidation rate was observed with TCE and DCM. PCE is known as a toxic organic compound, resistant to biodegradation. Therefore, the reduction of methane oxidation in soil by PCE could be attributed due to its toxicity effect. Normally, methanotrophs have methane monooxygenase (MMO) which is a highly non-specific enzyme. MMO can oxidize many chlorinated ethenes such as TCE, vinyl chloride and vinylidene chloride (Fogel et al, 1986). No evidence was found about biodegradation of PCE by methanotrophs even at concentrations as low as $0.2 \mathrm{ppm}$ (Fogel et al, 1986). However, PCE was found to be biodegraded in the absence of oxygen with the production of TCE and vinyl chloride (Vogel and McCarty, 1985). The biodegradation products such as TCE showed inhibition on methane oxidation in mixed culture of methanotrophs (Broholm et al, 1990).

As seen in Figure 1, increase in benzene concentration above $15 \mathrm{ppmv}$ was found to decrease methane oxidation rate at the higher rate. In general, benzene can be biodegraded by many microbes found in the soil such as Pseudomonas spp. The bacteria transform benzene to acids that are readily utilized further by microorganisms for cell synthesis and energy (Eweis et al, 1998). This biotransformation can occur in aerobic condition and may help to reduce the benzene concentration exposed to methanotrophs. Unlike PCE, benzene did not exhibit inhibition to methane oxidation at low concentrations (up to $15 \mathrm{ppmv}$ ). This may be due to the fact that benzene could be relatively 
easily biodegraded by other microbes in the soil samples, compare to the other three VOC.

The inhibition trend by TCE and DCM was different when compared with benzene and PCE, as seen in Figure 2. High reduction in methane oxidation rate was observed in both cases at VOC concentration of about 10 ppmv.. At this concentration, the methane oxidation rate reduced to $10 \%$ of the methane oxidation rate of control soil. This suggests that TCE and DCM have higher capacities to inhibit methane oxidation compared to benzene and PCE. It is known that TCE is one of the co-metabolized substrates for methane monooxygenase (MMO), whereas DCM can be directly assimilated into cell as carbon source via enzyme dichloromethane dehalogenase by methanotrophs (Wackett, 1995). The products of TCE and DCM degradation by methanotrophs are TCE-epoxide and formaldehyde, respectively. TCE-epoxide is an unstable compound that can be oxidized subsequently to carbon dioxide, whereas formaldehyde can be used directly by methanotrophs.

Oldenhuis et al. (1989) found that TCE was not toxic to methanotrophic culture below $15 \mathrm{mg} / \mathrm{L}$ concentration. However, the methane degradation can be inhibited by TCE at a concentration of 1.8 $\mathrm{mg} / \mathrm{L}$ in mixed culture of methane oxidizing bacteria (Broholm, 1990). McFarland et al. (1992) reported a mechanism of competitive inhibition of TCE on methane oxidation. In line with the above studies of methanotrophic culture, it was assumed that the reduction of the methane oxidation found in soils exposed to VOCs might be due to the competitive-inhibition mechanisms. Using this assumption, it was confirmed by fitting the experimental data of each compound into the equation (1). The results showed that experimental results of methane oxidation rate in various TCE and DCM concentration could fit well to the competitive-inhibition model as shown in Figure 2 with half velocity constants $0.09 \mathrm{mg}\left(r^{2}=0.981\right)$ and $0.11 \mathrm{mg}\left(r^{2}=0.9885\right)$, respectively. This suggests that the reduction of methane oxidation rate in soil exposed to TCE and DCM was the result of the competitive-inhibition mechanisms. However, this assumption may be valid only at low VOC concentrations. At very high VOC concentrations, the toxicity effect could result in the reduction in methanotrophic activities, because TCE concentrations above $25 \mathrm{mg} / \mathrm{L}$ were found toxic to the growth of methanotrophs bacteria (Oldenhuis et al, 1989). It was noted that the calculated methane oxidation rate by competitiveinhibition equation of benzene and PCE experiments did not correlate with the experimental results (Benzene, $r^{2}=0.6318$; PCE, $r^{2}=0.6612$ ). This suggests the simulated landfill soil exposed to benzene and PCE did not involve in the competitive-inhibition interaction. Moreover, the results indicate that the methane oxidation in actual landfill cover soil might be reduced by the amount/type of VOC in landfill gas with the different inhibition mechanisms.

\section{Effect of Mixed VOCs on Methane Oxidation} Activity: In this experiment, the effect of mixture of VOCs on methane oxidation activity was studied and compared to soil with single VOC and control sample. The results are shown in Figures 3. The experimental results revealed slightly higher inhibition effect by mixture of benzene and PCE at a total VOC concentration of 21.5 ppmv compared with single VOC application (benzene or PCE). As discussed in the previous section, increase in benzene and PCE concentrations could inhibit methane oxidation. The presence of both VOC compounds could increase in the total VOC concentration, which results in higher inhibition effect to methane oxidation when exposed to benzene and PCE mixture.

In soils exposed to the mixtures of DCM with PCE (25.3 ppmv), benzene (19.0 ppmv), and TCE (22.4 ppmv), methane oxidation rates were found to be zero (Table 2). In case of mixture of DCM with benzene or PCE, the termination of methane oxidation could be due to the presence of DCM. It is highly competitive inhibition to methane oxidation as discussed earlier. Similar results found in the mixture of DCM and TCE or the mixture of all VOCs. These results suggest that increase in types of VOC could result in higher inhibition effect on methane oxidation. This suggests that in actual landfills, combination of several VOCs may be highly toxic to methanotrophs due to synergistic effect. 
Table $2-\mathrm{CH}_{4}$ Oxidation Rate in Soils under various Mixed VOCs.

\begin{tabular}{lll}
\hline Conditions & $\begin{array}{l}\text { Total VOC concentrations in headspace } \\
(\mathrm{ppmv})\end{array}$ & $\begin{array}{l}\mathrm{CH}_{4} \text { oxidation rates } \\
\left(\mathrm{mg} \mathrm{CH}_{4} / \mathrm{g} \text { soil-d) }\right.\end{array}$ \\
\hline No VOCs & 0 & 0.302 \\
Benzene & 7.56 & 0.254 \\
PCE & 13.9 & 0.238 \\
TCE & 11 & 0.062 \\
DCM & 11.4 & 0.031 \\
PCE + Benzene & $13.9+7.6=21.6$ & 0.185 \\
DCM+ Benzene & $11.4+7.6=19.0$ & 0 \\
DCM + PCE & $11.4+13.9=25.3$ & 0 \\
DCM + TCE & $11.4+11=22.4$ & 0 \\
DCM + TCE + PCE + Benzene & $7.56+13.9+11.4+11=50.2$ & 0 \\
\hline N $:$ Eat
\end{tabular}

Note: Each set was conducted on duplicate samples.

Effect of VOC on Methanotrophic Cell Structure: Cultures of methanotrophs under different VOCs were studied and the cultures were harvested to observe cell structure using TEM. In culturing step, it was found that Methylomonas methanica could not grow at DCM concentration of 5 ppmv. However, it could grow at TCE, PCE and benzene concentrations at $5 \mathrm{ppmv}, 42 \mathrm{ppmv}$ and $30 \mathrm{ppmv}$, respectively. Cultures under TCE and PCE were selected for investigating through TEM. Observation of cell structure by TEM showed the loss of internal membrane content of methanotrophic cells exposed to TCE and PCE as seen in Figures 4. This internal membrane is the site attachment for pMMO (particulate methane monooxygenase) of type I methanotrophs. Beside this, increase of vesicles was found in the cells under TCE vapor while increase of pigments was found in the cells under PCE vapor. Disappearance of internal membrane is believed to be due to the loss of pMMO in methanotrophs. This suggests that the damage of internal structure caused by VOC may be one of the factors controlling methane oxidation capacity of the cells.

\section{CONCLUSION}

Effects of volatile organic compounds (VOCs) on methane oxidation in simulated landfill cover soil were investigated. An increase in VOC concentrations resulted in increase in reduction of methane oxidation rate. However, the effect of individual VOC on the reduction of methane oxidation rate was different. TCE and DCM showed greater inhibition to methane oxidation rate than benzene and PCE. The reduction of methane oxidation rate caused by benzene or PCE could be due to toxicity effect, whereas inhibition by TCE and DCM may result from the co- metabolic competitive-inhibition to methane oxidation. The competitive-inhibition mechanism gave high inhibition in methane oxidation. Soil with mixture of VOCs was found to have greater inhibition effect to methane oxidation compared to the soil with single VOC. Presence of DCM always resulted in significant reduction of methane oxidation. TEM examination of culture of methanotrophs exposed to VOCs suggested the adverse effect on internal structure of methanotrophic cells.

This research demonstrates that methanotrophic activity in actual landfills could be affected by volatile organic compound in landfill gas. The more types/concentrations of VOCs present in landfill gas, the higher inhibition in methane oxidation can be expected. Thus, in designing a final cover to reduce methane emission through application of microbial activity, VOC emission is a significant parameter to be considered. Minimization of VOCs in landfill gas through landfill management may be an alternative measure to prevent the VOC emission. Because of the inevitable presence of VOC in landfill gas, further study on treatment of VOCs is needed to reduce the inhibition effect on methane oxidation.

\section{RESUMO}

Os efeitos dos compostos orgânicos voláteis (VOCs) na oxidação do metano em camadas superficiais do solo. Os experimentos foram conduzidos usando somente VOCs ou mistura do mesmo, como, diclorometano (DCM), tricloroetileno (TCE), tetracloroetileno (PCE), e benzeno. Os resultados de todas as combinações mostraram uma diminuição na taxa da oxidação do metano com aumento nas concentrações de VOC. Além disso, os efeitos da inibição de TCE e de 
DCM foram mais elevados do que do benzeno e PCE. A redução da oxidação do metano pelo benzeno e PCE poderia ser atribuída ao efeito da toxicidade, visto que TCE e DCM exibiram o efeito de competição-inibição. Quando o solo foi misturado com o DCM, nenhuma oxidação do metano foi encontrada. Os danos à membrana interna celular foi observada em uma cultura metanotrófica exposta aos gases de VOC que é o local de ligação de uma enzima chave necessário para a oxidação do metano.

\section{REFERENCES}

Air Resources Board (1989), The Landfill Gas Testing Program: a Second Report to the California Legislature. Stationary Source Division, State of California, USA.

Allen, M. R.; Braithwaite, A. and Hills, C. C. (1997), Trace Organic Compounds in Landfill Gas at Seven U.K. Waste Disposal Sites. Environ. Sci. Technot., 31(4), 1054-1061

Alvares-Cohen, L. and McCarty, P. L., (1991), Product Toxicity and Cometabolic Competitive Inhibition Modeling of Chloroform and Trichloroethylene Transformation by Methanotrophic Resting Cells. Appl. Environ. Microbio. 57(4), 1031-1037

Boeckx, P. and Cleemput, O. V. (1996). Methane Oxidation in a Natural Landfill Cover Soil: Influen of Moisture Content, Temperature, and NitrogenTurnover. J. Environ. Qual. 25, 178-183

Borjesson, G. and Svensson, B. H. (1997), Seasonal and Diurnal Methane Emissions From Landfill and Their Regulation by Methane Oxidation. Waste Management and Research. 15, 33-54

Broholm, K.; Jensen, B. K.; Christensen, T. H. and Olsen, L. (1990), Toxicity of 1,1,1- Trichloroethylene on a Mixed Culture of Methane-Oxidizing Bacteria. Appl. Environ. Microbio. 56(8), 2488-2493

Fogel, M. M.; Taddeo, A. R. and Fogel, S. (1986), Biodegradation of Chlorinated Ethenes by a MethaneUtilzing Mixed Culture. Appl. Environ. Microbio. 51(4), 720-724

Eweis, J. B.; Ergas, S. J.; Chang, D. P. Y. and Schroeder, E. D., 1998, Bioremediation Principles. The McGraw Hill Companies, ISBN: 0-07-115719-0.

Humer. M, and Lechner. C., (1999), Compost as A Landfill Cover Material for the Elimination of Methane Emissions. Proceeding of the International Conference ORBIT 99 on Biological Treatment of Waste and the Environment Part II. September 24,1999: Weimar Ferderal Republic of Germany.
Intergovernmental Panel on Cilmate Change (IPCC), (1992): Climate Change: The IPCC Scientific Assessment. J. T. Houghton, G. J. Jenkins and J. J. Ephraums (eds.), Cambrigde University Press, Cambridge, UK.

McFarland, M. J.; Vogel, C. M. and Spain, J. C. (1992), Methanotrophic Cometabolism of Trichloroethylene (TCE) in a Two Stage Bioreactor System. Wat. Res. 26(2), 259-265

Oldenhuis R.; Vink, L. J.; Janssen, D. B. and Witholt, B. (1989), Degradation of Chlorinated Aliphatic Hydrocarbons by Methylosinus trichosporium OB3B expressing soluble methane monooxygenase. Appl. Environ. Microbio. 55, 2819-2826

Scott, D.; Brannan, J. and Higgin, I. J. (1981), The Effect of Growth Conditions on Intracytoplasmic Membranes and Methane Mono -oxygenase Activities in Methylosinus trichosporium OB3b. J. Gen Micro. 125, 63-72

Visvanathan, C.; Pokhrel, D.; Chiemchaisri, W.; Hettiaratchi, J. P. A. and Wu., J. (1999), Methanotrophic Activities in Tropical Landfill Cover Soils: Effects of Temperature, Moisture Content, and Methane Concentration. Waste Management and Research, 17, 313-323

Vogel, T. M. and McCarty, P. L. (1985), Biotransformation of Tetrachloroethylene to Trichloroethylene, Dichloroethylene, Vinyl Chloride, and Carbon Dioxide under Methnogenic Conditions. App. Environ. Microbio., 49(5), 1080-1083

Wackett, L. P. (1995), Bacterial Co-Metabolism of Halogenated Organic Compounds. In Microbial Transformation and Degradation of Toxic Organic Chemicals. Edited by Lily Y. Young, and Carl E. Cerniglia. Wiley-Liss, Inc., NY, USA.

Ward, R. S.; Williams, G. M. and Hills, C. C. (1996), Changes in Major and Trace Components of Landfill Gas During Subsurface Migration. Waste Mangement and Research, 14, 243-261

Whalen, S. C.; Reeburg, W. S. and Sandbeck, K. A. (1990), Rapid Methane Oxidation Rate in Landfill Cover Soil. Appli.Environ. and Microbiol., 56, 34053411

Whittenbury, R.; Phillips, K. C. and Winkinson, J. F. (1970), Enrichment, Isolation and Some Properties of Methane-Utilizing Bacteria. J. of Gen. Microb., 61, 205-218
Received: November 13, 2000; Revised: January 03, 2001; Accepted: February 29, 2001. 